\title{
COMPARATIVE STUDIES ON THE CATALATIC REACTION BETWEEN RED CELL SUSPENSION AND HEMOLYSATE
}

\author{
HIROSHI FUNAKI* \\ Department of Physiology, Kyoto Prefectural Medical University
}

We have very often observed that a cell or a tissue has a different biophysico-chemical activity from that of its homogenate. For instance, as is mentioned in the previous report (1), in red cell suspension no spontaneous deactivation of catalase occurs so long as there is no hemolysis, while a marked deactivation takes place spontaneously in hemolysate. In the present study, the difference in reaction type of catalase between red cell suspension and hemolysate was investigated.

MATERIAL AND METHOD

Catalatic reactions of diluted blood of various vertebrates were investigated by the thermoanalytical method (1). Fifty $\mathrm{ml}$. of the diluted blood (red cell suspension or hemolysate) prepared in the same manner as described in the previous report (1) and $50 \mathrm{ml}$. of $0.05 \mathrm{M} \mathrm{H}_{2} \mathrm{O}_{2}$ solution with or without $0.16 \mathrm{M}$ phosphate buffer, were made to react in the calorimeter. Temperature-change in the reaction system, $\Delta T$, was measured with time, $t$, and analysed. From the thermoanalytical equation,

$$
\begin{aligned}
& \frac{d T}{d t}+K \Delta T=\frac{Q}{W} \frac{d x}{d t}, \\
& K: \text { the cooling constant of the reaction system } \\
& W: \text { the water equivalent of the reaction system. } \\
& Q: \text { the decomposition heat of } \mathrm{H}_{2} \mathrm{O}_{2} .
\end{aligned}
$$

the reaction velocity, $\frac{d x}{d t}$, is obtained. As the main part of the reaction is of the first order, the reaction velocity constant, $k_{1}$, is also obtained from the slope of the straight part of the $\log \frac{Q}{W} \frac{d x}{d t} \sim t$ curve. The temperature of the experiment is always $25^{\circ} \mathrm{C}$. In this paper, the catalase activity or the velocity constant of the first oder reaction, $k_{1}$, is expressed in reciprocal minutes.

Received for publication November 17, 1956.

* 舟木 広 
RESULTS

Fig. 1 and fig. 2 demonstrate the reactions by various concentrations of human hemolysate and red cell suspension, respectively. The $\Delta T \sim t$ curve of hemolysate (fig. 1) is apparently a smooth, hyperbolic curve, while, in case of red cell suspension (fig. 2) especially of low concentrations, the $\Delta T \sim t$ curves, take a slight S-shape toward the end of the reaction, showing an inflection point. Furthermore, as is evident from a $\log \frac{Q}{W} \frac{d x}{d t} \sim t$ curve, in case of hemolysate, especially of low concentrations, the final part of the curve deviates from a straight part, bends upwards; that is, the retarded stage (2) (what Williams (3) call induced inactivation) appears, deviating from the main first order reaction. On the contrary in red cell suspension the reaction velocity is accelerated following the 1st order reaction as indicated by arrows in fig. $2 b$.

The reaction with red cell suspension, that with hemolysate and changes in the rate of reaction by using blood catalase once affected by $\mathrm{H}_{2} \mathrm{O}_{2}$ are comparatively shown in fig. 3. Human blood was used in all these observations. By comparing the velocity constant of catalatic reaction between red cell suspension and hemolysate, one may notice that the velocity constant is a few times larger in hemolysate than in red cell suspension in spite of both containing the same amount of catalase. When a certain amount of $\mathrm{H}_{2} \mathrm{O}_{2}$ has been added to the test solution before using it for the observation, red cell suspension shows a much larger reaction velocity compared with that in ordinary red cell suspension, while the velocity is reduced in hemolysate. The activity of catalase of hemolysate becomes weaker progressively in proportion to the concentration of $\mathrm{H}_{2} \mathrm{O}_{2}$ previously used.

\section{DISCUSSION}

Of the above findings the important point to consider is why the rate of catalatic reaction of red cell suspension is increased when the red cell suspension has been treated beforehand with $\mathrm{H}_{2} \mathrm{O}_{2}$. The catalase molecules in the red cell cannot be supposed to be activated by $\mathrm{H}_{2} \mathrm{O}_{2}$, neither the cell is hemolysed by it. The author has previously found (1) that the apparent activation energy for catalatic reaction is $7.2 \mathrm{Cal}$. in red cell suspension and $13.9 \mathrm{Cal}$. in hemolysate. Considering that the rate of reaction in hemolysate indicates directly the rate of decomposition of $\mathrm{H}_{2} \mathrm{O}_{2}$, the smaller rate in red cell suspension must depend upon some other factor, very probably the rate of diffusion of $\mathrm{H}_{2} \mathrm{O}_{2}$ into the cell. Coincidentally with this consideration, we noticed that the reaction in red cell suspension was considerably accelerated by stirring the reaction system $(4,5)$.

Granted that the above assumption is true, we may conclude that the structure of the cell membrane is changed by the effect of $\mathrm{H}_{2} \mathrm{O}_{2}$ in the sense of increase in its permeability. Concomitantly with this change, the red cell is fixed so that its hemolysis no longer occurs by the effect of distilled water, saponin, etc. as will be described in the next paper.

In the previous paper (2), the author reported that the blood catalase reaction in hemolysate develops in three stages - the initial stage, steady stage (the 1st order) and retarded stage. With red cell suspension, however, the last 


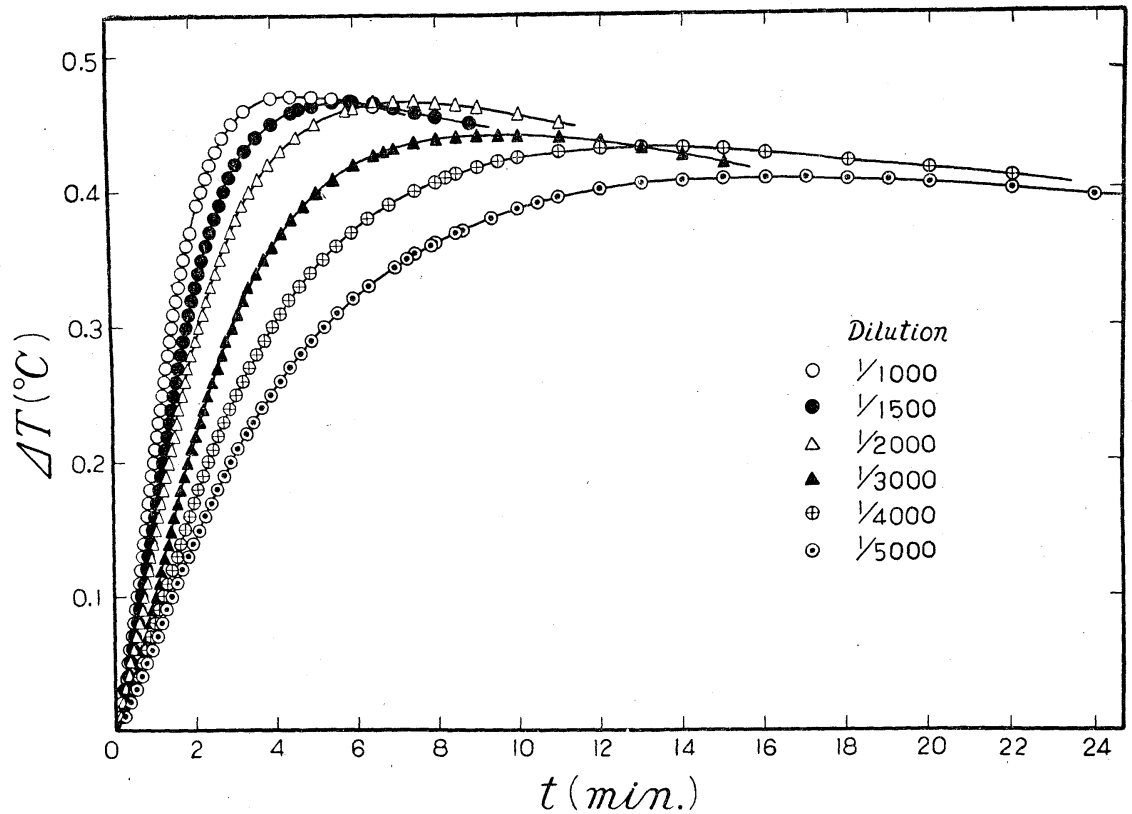

FIG. $1 a$

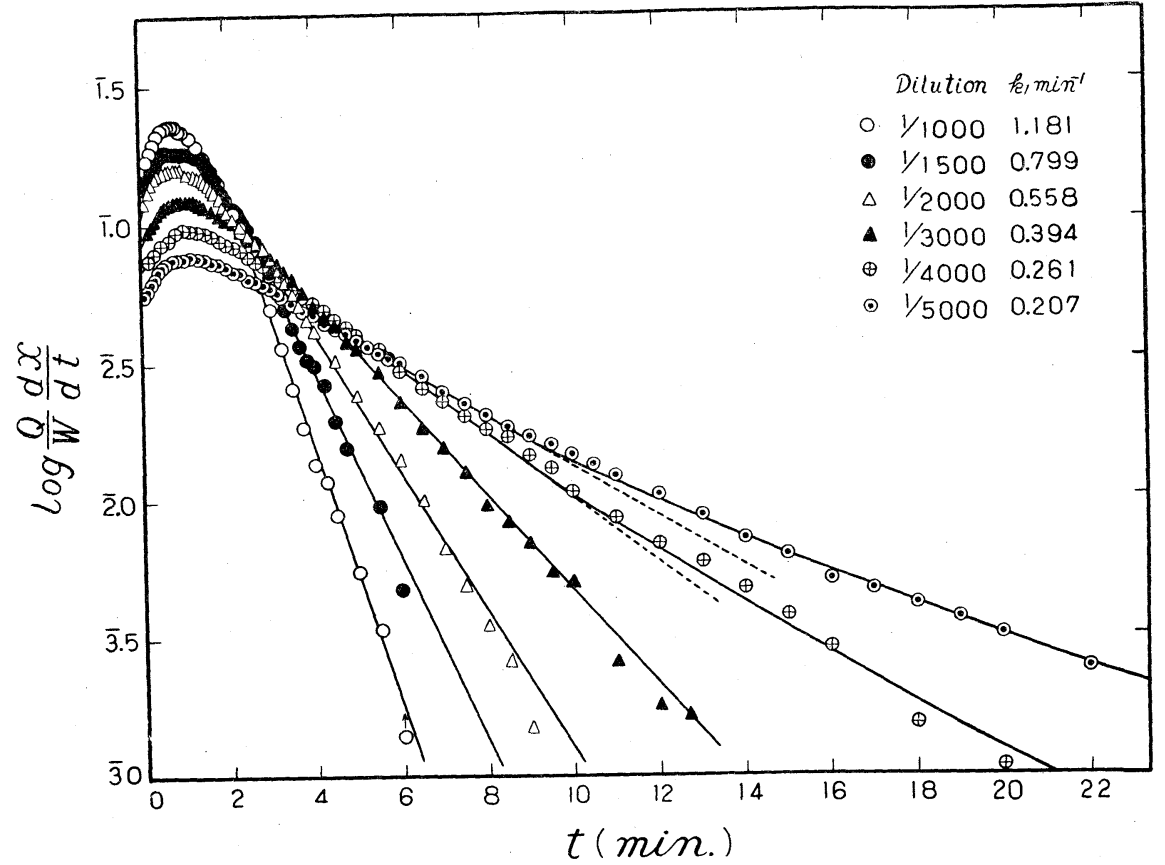

FIG. $1 b$

FIG. 1. Reaction between hemolysates in which human blood is diluted $1,000-5,000$ times with $0.016 \mathrm{M}$ phosphate buffer $(p \mathrm{H} 6.8)$ and $0.05 \mathrm{M}$ hydrogen peroxide solution. 


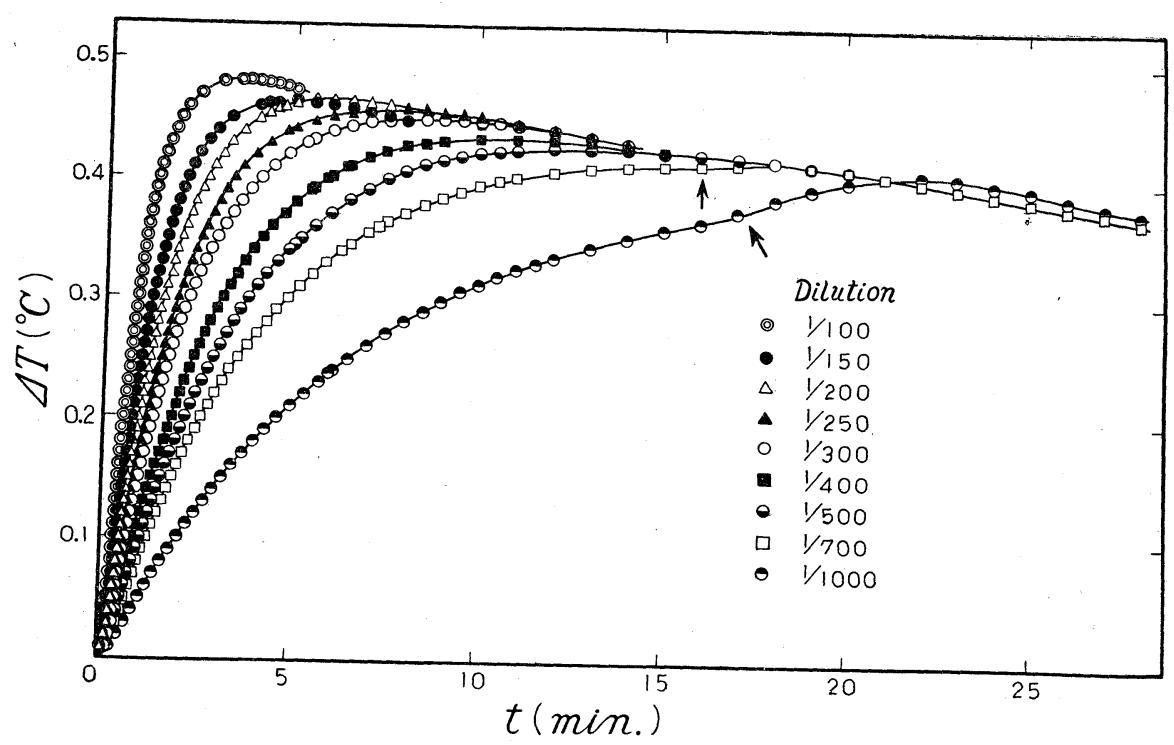

FIG. $2 a$

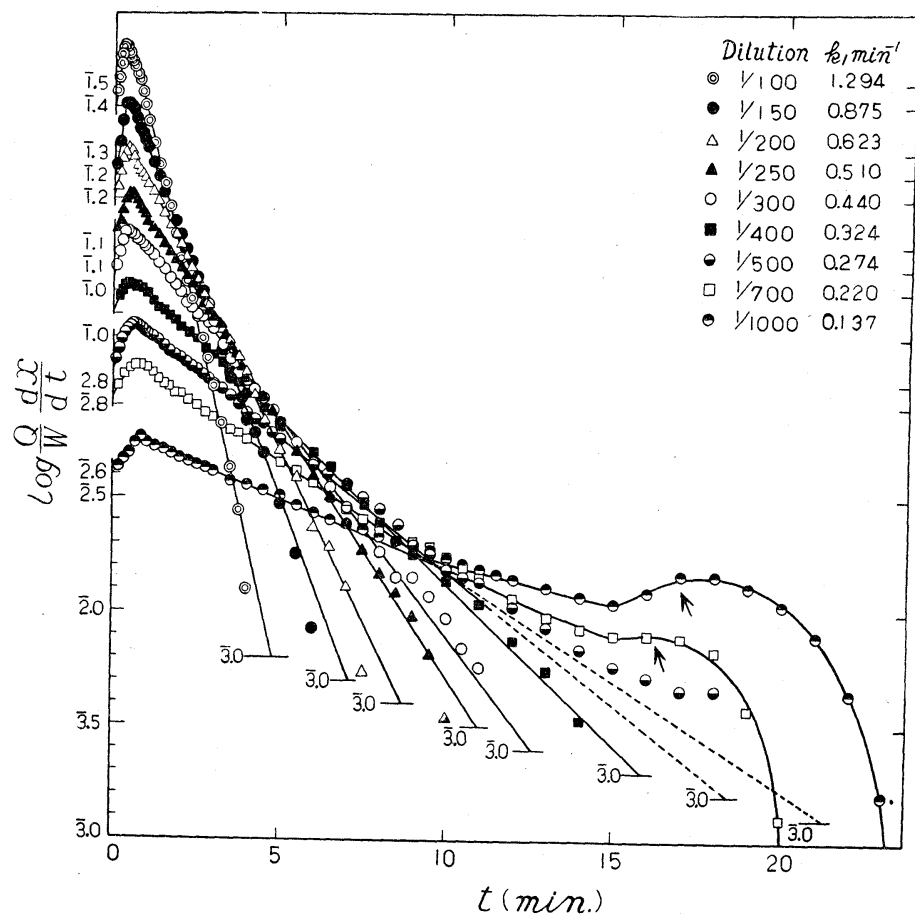

FIG. $2 b$

FIG. 2. Reaction between red cell suspensions in which human blood is diluted $100-1,000$ times with $0.16 \mathrm{M}$ phosphate buffer $(p \mathrm{H} 6.8)$ and $0.05 \mathrm{M}$ hydrogen peroxide solution containing $0.16 \mathrm{M}$ phosphate buffer. 


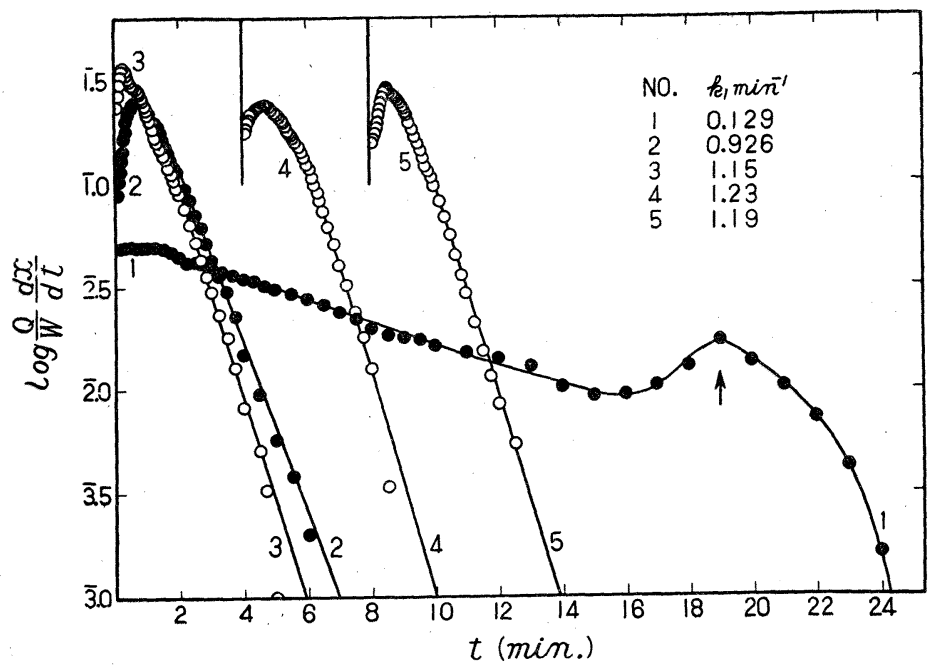

FIG. 3. Comparison between the catalatic reaction by red cell suspension and that by hemolysate (man). Though the ordinate is displaced for each curve, the scale of both ordinate and abcissa is equal. No. 1: Reaction by red cell suspension ( $1: 1,000$ diluted blood with $0.16 \mathrm{M}$ phosphate buffer). No. 2: Reaction by $1: 1,000$ diluted red cell suspension prepared by adding $25 \mathrm{ml}$. of $0.05 \mathrm{M} \mathrm{H}_{2} \mathrm{O}_{2}$ solution containing $0.16 \mathrm{M}$ phosphate buffer to $25 \mathrm{ml}$. of $1: 500$ diluted blood with $0.16 \mathrm{M}$ phosphate buffer. No. 3: Reaction between the hemolysate containing $0.16 \mathrm{M}$ phosphate buffer (dilution of blood, $1: 1,000$ ) and $\mathrm{H}_{2} \mathrm{O}_{2}$ solution containing $0.16 \mathrm{M}$ phosphate buffer. No. 4: Reaction by the hemolysate containing $0.016 \mathrm{M}$ phosphate buffer (dilution of blood, 1:1,000). No. 5: Reaction by the hemolysate (dilution of blood, $1: 1,000$ ) prepared by adding $25 \mathrm{ml}$. of $0.05 \mathrm{M} \mathrm{H}_{2} \mathrm{O}_{2}$ solution to $25 \mathrm{ml}$. of hemolysate containing $0.032 \mathrm{M}$ phosphate buffer (dilution of blood, $1: 500$ ).

stage does not appear as shown in fig. $2 b$. This is probably so because the retarded phenomenon is counteracted by acceleration due to increase in permeability above mentioned. In the character of action of catalase there seems to be no difference whether it is in the cell or dissolved in the plasma.

\section{SUMMARY}

1. The rate constant of the catalatic reaction of hemolysate is only a few times as large as that of the catalatic reaction of red cell suspension.

2. The activity of hemolysate catalase once treated with $\mathrm{H}_{2} \mathrm{O}_{2}$ is reduced in proportion to the concentrations of $\mathrm{H}_{2} \mathrm{O}_{2}$ previously added. On the contrary, the velocity of the catalatic reaction of red cell suspension once treated with $\mathrm{H}_{2} \mathrm{O}_{2}$ is a few times as large as that in the original red cell suspension.

3. When the amount of red cell is small in both red cell suspension and hemolysate, a retarded stage appears in their catalatic reactions, but in case of red cell suspension, the acceleration of hydrogen peroxide decomposition appears at the same time.

4. The rate of catalatic reaction in red cell suspension seems to be determined by the rate of diffusion, which may be increased by $\mathrm{H}_{2} \mathrm{O}_{2}$. 
A part of this study was read before the 10th local meeting of Japanese Physiological Society held in Kanazawa, in July 1955.

\section{REFERENCES}

1. Funaki, H. Thermal Analysis of Blood Catalase Reaction. Jap. J. Physiol. 5 : 183, 1955.

2. FUNAKI, H. On the Retarded Stage (the so-called Induced Inactivation) of Catalatic Reaction. J. Kyoto Pref. Med. Univ. 58: 651, 1955.

3. Williams, J. The Decomposition of Hydrogen Peroxide by Liver Catalase. J. Gen. Physiol. 11 : 309, 1928.

4. FUNAKI, H. Rate determing step of catalatic reaction by red cell suspension. J. Kyoto Pref. Med. Univ. in press.

5. Funaki, H. ET AL. Catalatic Reaction by Nucleated Red Cell Suspension. J. Kyoto Pref. Med. Univ. in press. 